\section{The Residual Effect of}

\section{1-Methylcyclopropene on Protecting Phalaenopsis Flowers against Ethylene Injury}

\author{
Jiunn-Yan Hou, Wei-Li Lin, Nean Lee, and Yao-Chien Alex Chang ${ }^{1}$ \\ Department of Horticulture and Landscape Architecture, National Taiwan \\ University, 1 Roosevelt Road Sec. 4, Taipei 10617, Taiwan
}

Additional index words. temperature, flower maturity, flower senescence, ethylene receptor, moth orchid

\begin{abstract}
Phalaenopsis flowers are prone to wilting under ethylene $\left(\mathrm{C}_{2} \mathrm{H}_{4}\right)$ stress. 1-Methylcyclopropene (1-MCP) can protect Phalaenopsis flowers against ethylene injury. In this study, we determined the residual effect of 1-MCP and how it is affected by temperature. The efficacy of multiple applications of 1-MCP was also investigated. The residual effect of 1-MCP was determined by pretreating blooming Phalaenopsis amabilis plants with $0.8 \mu \mathrm{L} \cdot \mathrm{L}^{-1} 1$-MCP for 8 hours on Day 0 followed by $2 \mu L \cdot L^{-1}$ ethylene fumigation for 12 hours on designated days. Without 1-MCP pretreatment, flowers began to wilt within 2 days after exposure to ethylene. Duration of the residual protection of $1-\mathrm{MCP}$ on $P$. amabilis was $\approx 6$ to 8 days during summer in Taiwan. Lower temperatures after 1-MCP application prolonged protection times. The full protection times under day/night temperatures of $25 / 20,20 / 15$, and $15 / 13{ }^{\circ} \mathrm{C}$ were 4 to 8,10 to 13 , and 13 to 17 days, respectively. Furthermore, multiple applications of 1-MCP extended the duration of 1-MCP protection against ethylene. Three applications increased the residual protection of $P$. amabilis by $1-\mathrm{MCP}$ to at least 24 days.
\end{abstract}

Phalaenopsis spp. have become popular commodities in the world; their long-lasting flowers are an attractive characteristic for consumers. The postharvest life of potted Phalaenopsis can extend to more than 3 months. Like most orchids, however, the Phalaenopsis flower is susceptible to $\mathrm{C}_{2} \mathrm{H}_{4}$ stress (Hew and Yong, 2004). Exposure of Phalaenopsis Snow Mist 'Large Sepal' flowers to $0.09 \mu \mathrm{L} \cdot \mathrm{L}^{-1}$ ethylene for $66 \mathrm{~h}$ resulted in wilting (Lee and Lin, 1992). Ethylene can come from many sources such as emissions from internal combustion engines, pollutants released into the atmosphere, normal emissions from plant organs and from fungal metabolism, etc. (Martínez-Romero et al., 2007). Damaging concentrations of ethylene commonly occur during postharvest, transportation, and marketing and can reduce product quality.

1-Methylcyclopropene is an ethylene inhibitor that is widely used to maintain the freshness of ornamental plants and flowers and delay the ripening of fruits. 1-Methylcyclopropene works by tightly binding to ethylene receptors

Received for publication 5 June 2012. Accepted for publication 17 Aug. 2012.

Financial support was provided by the Council of Agriculture, Executive Yuan, Taiwan [96AS-1.2.1-ST-a1(4) and 97AS-1.2.1-ST-a1(3)]. This study is part of the theses submitted by Jiunn-Yan Hou and Wei-Li Lin in partial fulfillment of their Master of Science degree requirements.

${ }^{1}$ To whom reprint requests should be addressed; e-mail alexchang@ntu.edu.tw. in plants, thus competing with ethylene for available binding sites. The affinity of 1 -MCP for ethylene receptors is 10 times greater than that of ethylene. Therefore, once ethylene receptors are fully occupied by 1-MCP molecules, both endogenous and exogenous ethylene responses are inhibited (Serek et al., 2006).

The residual protection by 1-MCP against ethylene-induced effects is limited (Sisler and Serek, 1999). Cymbidium flowers subjected to 1-MCP pretreatment resisted ethylene stress for up to 2 weeks but wilted when ethylene was applied at Week 3 (PhilosophHadas et al., 2005). When ethylene receptors in plant tissues are fully blocked by $1-\mathrm{MCP}$, 7 to $12 \mathrm{~d}$ are required for $50 \%$ receptor regeneration (half diffusion time; Sisler and Serek, 1999). After that, the inhibitory efficacy on the ethylene response gradually decreases. Based on the abscission percentage after $2 \mathrm{~h}$ of ethylene exposure, the half-lives of 1-MCP activities in Pelargonium peltatum flowers were $\approx 2,3$, and $6 \mathrm{~d}$ after 1 -MCP treatment at $25,20.7$, and $12{ }^{\circ} \mathrm{C}$, respectively (Cameron and Reid, 2001), demonstrating that the residual effect of 1-MCP is affected by temperature.

Multiple applications of 1-MCP can be a strategy to prolong protection times. For example, apple fruit became soft $40 \mathrm{~d}$ after 1-MCP treatment, but multiple 1-MCP applications delayed the occurrence of ripening (Mir et al., 2001). A single application of $1-\mathrm{MCP}$ on green-mature tomatoes delayed fruit coloration by $6 \mathrm{~d}$, but a second application applied at $10 \mathrm{~d}$ after the first treatment delayed coloration for another 8 to $10 \mathrm{~d}$ (Mir et al., 2004). 1-Methylcyclopropene was reported to be efficacious in retarding ethyleneinduced flower wilting in Phalaenopsis (Lin et al., 2003; Segliea et al., 2010; Sun et al., 2009). Pretreating Phalaenopsis amabilis with $0.8 \mu \mathrm{L} \cdot \mathrm{L}^{-1} 1-\mathrm{MCP}$ for $4 \mathrm{~h}$ fully inhibited the wilting of flowers and flower buds (Lin et al., 2003). The residual effect of 1-MCP in Phalaenopsis is of great interest because it has emerged as an economically important potted plant. However, such information is not available in the literature.

In the current study, we determined the residual effect of 1-MCP in preventing ethylene damage to flowers and buds of $P$. amabilis. The effects of post-1-MCP-treatment temperatures and multiple 1-MCP applications on the residual efficacy were also investigated.

\section{Materials and Methods}

Plant materials. Phalaenopsis amabilis plants purchased from commercial nurseries were used. All plants were grown in $10.5-\mathrm{cm}-$ diameter, clear, soft plastic pots $(0.75 \mathrm{~L})$ that were tightly filled with sphagnum moss. Each plant had one (Expts. 1 and 3) or two (Expt. 2) inflorescences with the first flower bud nearly open. The total numbers of flowers and buds in an inflorescence were 13.5, 9.8, and 13.5 in Expts. 1, 2, and 3, respectively. Before the experiments began, plants were placed in a greenhouse until they reached a suitable stage of flowering maturity (approximately five open flowers on each inflorescence).

Application of 1-methylcyclopropene. 1Methylcyclopropene powder was obtained from Lytone Enterprise (Taipei, Taiwan). In this study, $0.8 \mu \mathrm{L} \cdot \mathrm{L}^{-1} 1-\mathrm{MCP}$ was used to treat plants for $8 \mathrm{~h}$ by the following procedure. In an indoor environment, plants were placed in sealable, polypropylene boxes $\left(0.225 \mathrm{~m}^{3}\right)$ containing a small electric fan. A mixture of $0.1 \mathrm{~g}$ of $1-\mathrm{MCP}$ and $2 \mathrm{~mL}$ of distilled water in a test tube was placed in each box. The boxes were then immediately sealed. After $8 \mathrm{~h}$, plants were moved out of the boxes for further treatments. The average temperature was $23 \pm 2{ }^{\circ} \mathrm{C}$.

Application of ethylene. Plants were treated with $2 \mu \mathrm{L} \cdot \mathrm{L}^{-1}$ ethylene for $12 \mathrm{~h}$ in this study. First, plants were placed in sealed boxes (the same as those used for 1-MCP application). Then appropriate volumes of high-concentration ethylene were injected into the boxes to achieve a concentration of $2 \mu \mathrm{L} \cdot \mathrm{L}^{-1}$. Concentrations of ethylene in the boxes were readjusted after $15 \mathrm{~min}$ by the following procedure. Air samples $(1 \mathrm{~mL})$ were taken from the boxes, and the concentration of ethylene was measured by a gas chromatograph (GC 14-A; Shimadzu, Tokyo, Japan) equipped with a Porapak Q column (80/100 mesh) and a flame ionization detector. Additional ethylene was injected if needed. After $8 \mathrm{~h}$, plants were immediately moved out of the boxes. The average experimental temperature was $23 \pm 2{ }^{\circ} \mathrm{C}$.

Expt. 1: The residual effect of 1-methylcyclopropene. The experiment began in August. 
Plants were divided into eight groups. Six groups were pretreated with 1-MCP on Day 0 and then were respectively treated with ethylene (as previously described) on Day 4, $6,8,10,12$, or 14 . There were two groups of controls: one group did not receive either 1-MCP or ethylene treatment (but were treated with fresh air), and the other group received ethylene treatment on Day 0 but no 1-MCP pretreatment. After 1-MCP or ethylene treatment, plants were placed indoors with a $12-\mathrm{h}$ photoperiod provided by fluorescent lights $\left(9 \mu \mathrm{mol} \cdot \mathrm{m}^{-2} \cdot \mathrm{s}^{-1}\right)$. Total combined number of flowers and buds in each inflorescence was counted before 1-MCP treatment. The combined number of wilted flowers and buds was recorded daily after ethylene treatment. The percentage of wilted flowers was calculated as the number of wilted flowers and buds divided by the total number of flowers and buds. We also noted the times necessary to reach percentages of flower wilting of greater than $0 \%, 50 \%, 70 \%$, and $100 \%$. The average room temperature was $24.7{ }^{\circ} \mathrm{C}$. Each treatment included eight single-plant replications. The experiment was performed twice with similar results. Results of the second experiment are reported here.

Expt. 2: The effect of temperature on the residual effects of 1-methylcyclopropene. All plants were pretreated with 1-MCP, after which they were placed in phytotrons with day/night temperatures of $25 / 20,20 / 15$, or $15 / 13{ }^{\circ} \mathrm{C}$. Plants under each temperature regimen were subjected to ethylene treatment at $0,4,8,10,13$, or $17 \mathrm{~d}$ after $1-\mathrm{MCP}$ pretreatment. Ethylene-treated plants were moved to an indoor environment with a $12-\mathrm{h}$ photoperiod provided by fluorescent lights $\left(8 \mu \mathrm{mol} \cdot \mathrm{m}^{-2} \cdot \mathrm{s}^{-1}\right)$ and an average room temperature of $22.1{ }^{\circ} \mathrm{C}$. Plants in the control groups received no ethylene treatment and were left at room temperature. The flowerwilting percentage was determined as described in Expt. 1. There were six single-plant replications for each treatment. Each plant had two inflorescences.

Expt. 3: The efficacy of multiple applications of 1-methylcyclopropene. To determine whether multiple applications of 1-MCP could prolong its residual effects on Phalaenopsis, plants were subjected to different repetitions of 1-MCP pretreatments and were treated with ethylene at different times. The experiment began in December. Plants were separated into nine groups. Seven of them were treated with 1-MCP for various times including one application of 1-MCP on Day 0 and fumigation with ethylene on Day 6 or 12; two applications of 1-MCP on Days 0 and 6 and fumigation with ethylene on Day 12 or 18; and three applications of 1-MCP on Days 0,6 , and 12 and fumigation with ethylene on Day 18,24 , or 30 . There were two groups of controls: one group did not receive either 1-MCP or ethylene treatment (the plants were only treated with fresh air), and the other group received ethylene treatment with no 1-MCP pretreatment. After 1-MCP treatment, plants were placed indoors under a $12-\mathrm{h}$ photoperiod provided by fluorescent lights $\left(9 \mu \mathrm{mol} \cdot \mathrm{m}^{-2} \cdot \mathrm{s}^{-1}\right)$. The flower-wilting percentage was determined as described in Expt. 1. The average room temperature was $19.5^{\circ} \mathrm{C}$. Each treatment consisted of six single-plant replications. The experiment was performed twice with similar results. Results of the first experiment are reported here.

Statistical analysis. All experiments were arranged in a completely randomized design. Daily flower-wilting percentages were graphed with SigmaPlot 10.0 (Systat Software, Inc., San Jose, CA). The numbers of days necessary to reach flower-wilting percentages of greater than $0 \%, 50 \%, 70 \%$, and $100 \%$ were determined and analyzed using CoStat 6.2 (CoHort Software, Monterey, CA). Means separation between treatments was determined using the least significance difference test at $P \leq 0.05$.

\section{Results}

Expt. 1: The residual effect of 1-methylcyclopropene. With neither 1-MCP nor ethylene treatment, the daily flower-wilting percentage of control plants gradually increased over time (Fig. 1), and the time to reach $50 \%$ flowerwilting (per plant) was $64.9 \mathrm{~d}$ (Table 1). In ethylene-treated plants with no 1-MCP pretreatment, the daily flower-wilting percentage increased rapidly from Day 2 after ethylene treatment (Fig. 1). Results showed that flowers of $P$. amabilis were very susceptible to ethylene. Plants protected by 1-MCP and subjected to ethylene treatment on Days 4 and 6 had similar rates of daily flower-wilting percentages to control plants (Fig. 1), and the time necessary to reach $50 \%$ flower-wilting (per plant) was 54.5 to $73.6 \mathrm{~d}$ (Table 1). Plants protected by 1-MCP and subjected to ethylene treatment on Day $8,10,12$, or 14 , however, showed sharply rising curves of daily flowerwilting percentages shortly after ethylene treatment (Fig. 1). These flowers began to wilt within $2 \mathrm{~d}$ after ethylene treatment, and these plants took shorter times to reach $50 \%$ flower wilting (12.6 to $35.5 \mathrm{~d}$ ) compared with the

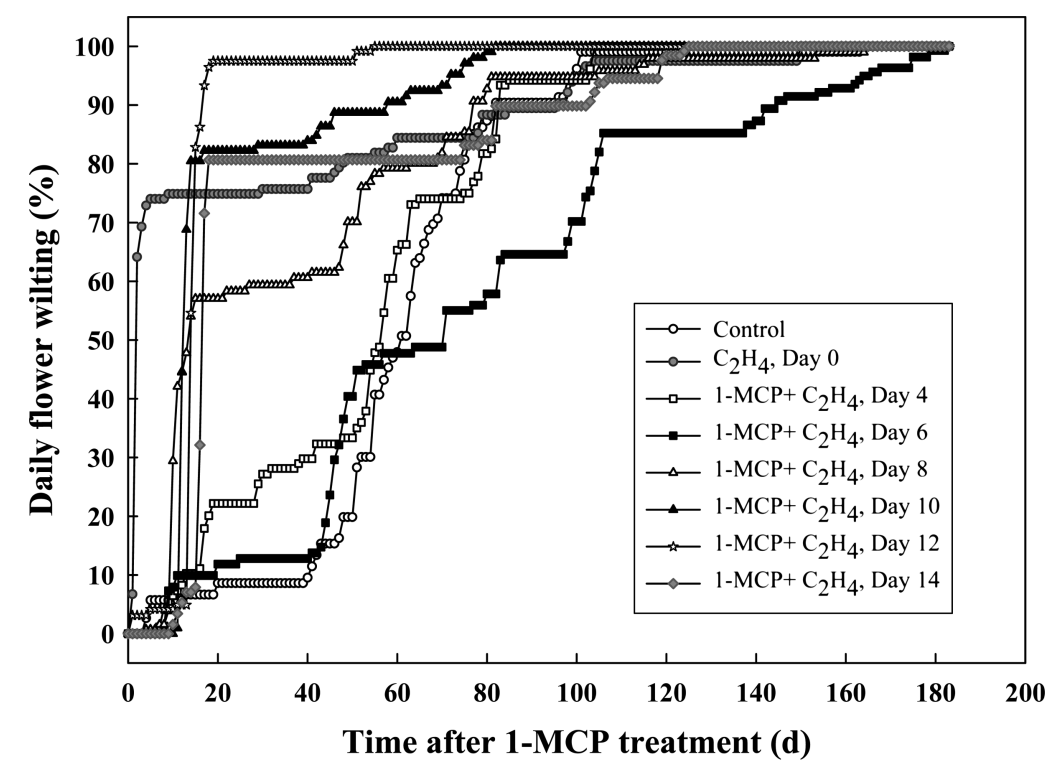

Fig. 1. Effect of 1-methylcyclopropene (1-MCP) against ethylene-induced flower wilting in Phalaenopsis amabilis. Plants were fumigated with $0.8 \mu \mathrm{L} \cdot \mathrm{L}^{-1} 1-\mathrm{MCP}$ on Day 0 for $8 \mathrm{~h}$ followed by ethylene $\left(2 \mu \mathrm{L} \cdot \mathrm{L}^{-1}\right)$ treatment for $12 \mathrm{~h}$ on Day $4,6,8,10,12$, or 14 . Control plants were treated with air but did not receive either 1 -MCP or ethylene application; $\mathrm{n}=8$.

Table 1. Residual effect of 1-methylcyclopropene (1-MCP) against ethylene-induced flower wilting in Phalaenopsis amabilis.

\begin{tabular}{llcccc}
\hline 1-MCP & Ethylene & \multicolumn{3}{c}{ Time to achieve a specific flower wilting percentage $(\mathrm{d})^{\mathrm{x}}$} \\
\cline { 2 - 5 } treatment $^{\mathrm{z}}$ & treatment $^{\mathrm{y}}$ & Greater than $0 \%$ & $50 \%$ & $70 \%$ & $100 \%$ \\
\hline Now $^{\mathrm{w}}$ & No (control) & $23.4 \mathrm{~b}^{\mathrm{v}}$ & $64.9 \mathrm{a}$ & $68.5 \mathrm{ab}$ & $81.6 \mathrm{ab}$ \\
No & Day 0 & $1.9 \mathrm{c}$ & $14.3 \mathrm{c}$ & $29.6 \mathrm{~cd}$ & $62.5 \mathrm{bc}$ \\
Yes & Day 4 & $30.3 \mathrm{~b}$ & $54.5 \mathrm{ab}$ & $60.8 \mathrm{abc}$ & $75.6 \mathrm{abc}$ \\
Yes & Day 6 & $53.0 \mathrm{a}$ & $73.6 \mathrm{a}$ & $84.1 \mathrm{a}$ & $100.6 \mathrm{a}$ \\
Yes & Day 8 & $9.1 \mathrm{bc}$ & $33.6 \mathrm{bc}$ & $45.5 \mathrm{bcd}$ & $66.3 \mathrm{abc}$ \\
Yes & Day 10 & $12.0 \mathrm{bc}$ & $12.6 \mathrm{c}$ & $30.0 \mathrm{bcd}$ & $43.6 \mathrm{bcd}$ \\
Yes & Day 12 & $12.0 \mathrm{bc}$ & $14.5 \mathrm{c}$ & $15.1 \mathrm{~d}$ & $21.1 \mathrm{~d}$ \\
Yes & Day 14 & $13.6 \mathrm{bc}$ & $35.5 \mathrm{bc}$ & $37.9 \mathrm{~cd}$ & $39.0 \mathrm{~cd}$ \\
\hline
\end{tabular}

"2Plants were treated with $0.8 \mu \mathrm{L} \cdot \mathrm{L}^{-1} 1-\mathrm{MCP}$ or left untreated for $8 \mathrm{~h}$ on Day 0 .

y Plants were fumigated for $12 \mathrm{~h}$ with $2 \mu \mathrm{L} \cdot \mathrm{L}^{-1}$ ethylene $4,6,8,10,12$, or $14 \mathrm{~d}$ after 1 -MCP pretreatment. ${ }^{\mathrm{x}}$ Calculated from Day 0 .

${ }^{\mathrm{w}}$ Control plants were treated with air but did not receive either 1-MCP or ethylene application.

${ }^{v}$ Means followed by different letters in a column are significantly different at $P \leq 0.05$ by the least significant difference test; $\mathrm{n}=8$. 
control plants (64.9 d; Table 1). These results showed that flowers and buds were unaffected by ethylene within $6 \mathrm{~d}$ after 1-MCP application, but the protection from ethylene provided by 1-MCP diminished from Day 8 onward. Also, it is worth mentioning that nearly open buds on an inflorescence of plants that received ethylene on Day 10 wilted earlier than younger, unopened buds and older flowers (Fig. 2). This showed that the residual effect of 1-MCP diminished earlier for nearly open buds than other buds and flowers.

These results showed that the residual effect of 1-MCP on protecting flowers against ethylene injury was sustained for 6 to $8 \mathrm{~d}$ in the current experiment. The experiment was repeated and similar results were obtained.

Expt. 2: The effect of temperature on the residual effects of 1-methylcyclopropene. All plants in this experiment were treated with $0.8 \mu \mathrm{L} \cdot \mathrm{L}^{-1} 1$-MCP for $8 \mathrm{~h}$. Plants not subjected to any temperature treatments showed similar flower-wilting rates regardless of whether they received any ethylene treatment (Table 2; Fig. 3). At $25 / 20{ }^{\circ} \mathrm{C}$, plants that received ethylene treatment on Day 4 showed similar rates of daily flower-wilting percentages to control plants (Fig. 3A). Ethylene treatments on Day 8,10,13, or 17, however, resulted in rapid increases in the daily flowerwilting percentages (Fig. 3A). Specifically, the times necessary for flower-wilting rates to reach greater than $0 \%, 50 \%$, and $100 \%$ were similar to controls when ethylene was applied on Day 4; however, the times necessary for flower-wilting rates to exceed $0 \%$ and $50 \%$ decreased when ethylene was applied on Day 8, but the time necessary for flower-wilting rates to reach $100 \%$ did not decrease (Table 2). This result indicated that only partial protection was still provided by $1-\mathrm{MCP}$ on Day 8. Ethylene treatments applied on subsequent days (Days 10, 13, or 17) resulted in reductions in the times necessary for flower-wilting rates to reach greater than $0 \%, 50 \%$, and $100 \%$ compared with control plants (Table 2). These results showed that the residual effect of 1-MCP against ethyleneinduced wilting at $25 / 20^{\circ} \mathrm{C}$ in Phalaenopsis flowers gradually decreased 4 to $8 \mathrm{~d}$ after 1-MCP treatment and was totally lost $10 \mathrm{~d}$ after 1-MCP treatment.

At $20 / 15{ }^{\circ} \mathrm{C}$, plants that had received ethylene on Days 4, 8, and 10 showed daily flower-wilting percentages similar to those of control plants, whereas plants that had been treated with ethylene on Days 13 and 17 showed early increases in flower-wilting percentages (Fig. 3B). The times necessary for flower wilting to reach greater than $0 \%, 50 \%$, and $100 \%$ in plants treated at $20 / 15^{\circ} \mathrm{C}$ were similar to those of the control plants when ethylene was applied on Days 4, 8, and 10 (Table 2). When ethylene was applied on Days 13 and 17, however, wilting began earlier than in control plants (Table 2). This result showed that at $20 / 15^{\circ} \mathrm{C}$, the residual effect of 1-MCP on ethyleneinduced wilting in Phalaenopsis flowers was partially lost 10 to $13 \mathrm{~d}$ after 1 -MCP treatment.

At $15 / 13{ }^{\circ} \mathrm{C}$, plants that had received ethylene on Days 4, 8, 10, and 13 showed similar

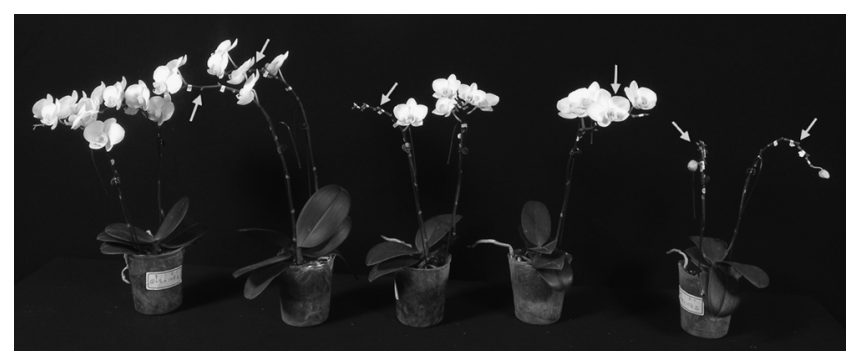

Fig. 2. Various degrees of flower wilting of Phalaenopsis amabilis pretreated with $0.8 \mu \mathrm{L} \cdot \mathrm{L}^{-1}$ 1-methylcyclopropene (1-MCP) for $8 \mathrm{~h}$ on Day 0 followed by $2 \mu \mathrm{L} \cdot \mathrm{L}^{-1}$ ethylene fumigation for $12 \mathrm{~h}$ on Day 10. The photograph was taken on Day 23 after 1-MCP treatment. Arrows indicate wilted buds, which were at the nearly open stage before $1-\mathrm{MCP}$ treatment.

Table 2. Effects of temperature on the residual efficacy of 1-methylcyclopropene (1-MCP) against ethylene-induced flower wilting in Phalaenopsis amabilis. ${ }^{\mathrm{L}}$

\begin{tabular}{|c|c|c|c|c|}
\hline \multirow{2}{*}{$\begin{array}{l}\text { Ethylene } \\
\text { treatment }^{\mathrm{y}}\end{array}$} & \multirow{2}{*}{$\begin{array}{l}\text { Temp treatment } \\
\left(\text { day/night, }{ }^{\circ} \mathrm{C}\right)^{\mathrm{x}}\end{array}$} & \multicolumn{3}{|c|}{ Time to achieve a specific flower-wilting percentage (d) } \\
\hline & & Greater than $0 \%$ & $50 \%$ & $100 \%$ \\
\hline No (control) & - & $81.3 \mathrm{a}^{\mathrm{u}}$ & $85.6 \mathrm{a}$ & $87.0 \mathrm{a}$ \\
\hline Day $0^{\mathrm{v}}$ & - & $73.8 \mathrm{a}$ & $79.0 \mathrm{a}$ & $82.3 \mathrm{a}$ \\
\hline \multirow[t]{3}{*}{ Day 4} & $25 / 20$ & $70.9 \mathrm{a}$ & $74.2 \mathrm{a}$ & $79.2 \mathrm{a}$ \\
\hline & $20 / 15$ & $71.9 \mathrm{a}$ & $81.0 \mathrm{a}$ & $84.1 \mathrm{a}$ \\
\hline & $15 / 13$ & $71.4 \mathrm{a}$ & $74.1 \mathrm{a}$ & $84.6 \mathrm{a}$ \\
\hline No (control) & - & $81.3 \mathrm{a}$ & $85.6 \mathrm{a}$ & $87.0 \mathrm{a}$ \\
\hline Day 0 & - & $73.8 \mathrm{a}$ & $79.0 \mathrm{a}$ & $82.3 \mathrm{a}$ \\
\hline \multirow[t]{3}{*}{ Day 8} & $25 / 20$ & $40.4 \mathrm{~b}$ & $54.0 \mathrm{~b}$ & $75.0 \mathrm{a}$ \\
\hline & $20 / 15$ & $77.4 \mathrm{a}$ & $80.5 \mathrm{a}$ & $87.2 \mathrm{a}$ \\
\hline & $15 / 13$ & $69.6 \mathrm{a}$ & $77.5 \mathrm{a}$ & $81.1 \mathrm{a}$ \\
\hline No (control) & - & $81.3 \mathrm{a}$ & $85.6 \mathrm{a}$ & $87.0 \mathrm{a}$ \\
\hline Day 0 & - & $73.8 \mathrm{a}$ & $79.0 \mathrm{a}$ & $82.3 \mathrm{a}$ \\
\hline \multirow{3}{*}{ Day 10} & $25 / 20$ & $14.4 \mathrm{~b}$ & $14.6 \mathrm{~b}$ & $46.1 \mathrm{~b}$ \\
\hline & $20 / 15$ & $81.0 \mathrm{a}$ & $82.9 \mathrm{a}$ & $87.6 \mathrm{a}$ \\
\hline & $15 / 13$ & $73.4 \mathrm{a}$ & $82.5 \mathrm{a}$ & $91.1 \mathrm{a}$ \\
\hline No (control) & - & $81.3 \mathrm{a}$ & $85.6 \mathrm{a}$ & $87.0 \mathrm{a}$ \\
\hline Day 0 & - & $73.8 \mathrm{ab}$ & $79.0 \mathrm{a}$ & $82.3 \mathrm{a}$ \\
\hline \multirow[t]{3}{*}{ Day 13} & $25 / 20$ & $16.2 \mathrm{c}$ & $17.4 \mathrm{~b}$ & $27.1 \mathrm{~b}$ \\
\hline & $20 / 15$ & $61.6 \mathrm{~b}$ & $70.6 \mathrm{a}$ & $80.6 \mathrm{a}$ \\
\hline & $15 / 13$ & $74.8 \mathrm{ab}$ & $82.6 \mathrm{a}$ & $88.2 \mathrm{a}$ \\
\hline No (control) & - & $81.3 \mathrm{a}$ & $85.6 \mathrm{a}$ & $87.0 \mathrm{a}$ \\
\hline Day 0 & - & $73.8 \mathrm{ab}$ & $79.0 \mathrm{a}$ & $82.3 \mathrm{a}$ \\
\hline \multirow{3}{*}{ Day 17} & $25 / 20$ & $19.9 \mathrm{~d}$ & $20.6 \mathrm{~b}$ & $20.9 \mathrm{~b}$ \\
\hline & $20 / 15$ & $49.9 \mathrm{bc}$ & $72.7 \mathrm{a}$ & $76.7 \mathrm{a}$ \\
\hline & $15 / 13$ & $58.4 \mathrm{bc}$ & $76.7 \mathrm{a}$ & $89.9 \mathrm{a}$ \\
\hline
\end{tabular}

${ }^{\mathrm{z}}$ All plants were pretreated with $0.8 \mu \mathrm{L} \cdot \mathrm{L}^{-1} 1-\mathrm{MCP}$ for $8 \mathrm{~h}$ on Day 0 .

yPlants were treated for $12 \mathrm{~h}$ with $2 \mu \mathrm{L} \cdot \mathrm{L}^{-1}$ ethylene on the designated days or left untreated and moved to an indoor environment to investigate the flower-wilting percentage.

${ }^{x}$ Plants were treated with $0.8 \mu \mathrm{L} \cdot \mathrm{L}^{-1} 1-\mathrm{MCP}$ for $8 \mathrm{~h}$ on Day 0 and transferred to phytotrons with day/night temperatures of $25 / 20,20 / 15$, or $15 / 13^{\circ} \mathrm{C}$.

${ }^{\mathrm{w}}$ Calculated from Day 0.

vAfter 1-MCP treatment, plants were immediately subjected to ethylene treatment and placed in an indoor environment with no temperature treatment.

${ }^{\text {u} W i t h i n ~ e a c h ~ g r o u p ~ o f ~ t r e a t m e n t s ~(e a c h ~ g r o u p ~ c o n t a i n e d ~ f i v e ~ r o w s ~ o f ~ t r e a t m e n t s), ~ m e a n s ~ f o l l o w e d ~ b y ~ d i f f e r e n t ~}$ letters in a column are significantly different at $P \leq 0.05$ by the least significant difference test; $\mathrm{n}=6$.

daily flower-wilting percentages to control plants, but the rate of wilting rose earlier when ethylene was applied on Day 17 (Fig. 3C). In other words, there were no differences in the times necessary for flower wilting to reach greater than $0 \%, 50 \%$, and $100 \%$ in plants treated with ethylene on Days $4,8,10$, and 13 , but wilting began earlier when ethylene was applied on Day 17 compared with controls (Table 2). These results indicated that at $15 / 13{ }^{\circ} \mathrm{C}$, the residual effect of 1 -MCP against ethylene-induced wilting in Phalaenopsis flowers was partially lost 13 to $17 \mathrm{~d}$ after 1-MCP treatment.
These results showed that the efficacy of 1-MCP against ethylene-induced wilting in $P$. amabilis flowers was gradually lost over time but was sustained for various durations at different temperatures. Higher temperatures resulted in shorter protection times. In this study, full 1-MCP protection was sustained for 4 to $8 \mathrm{~d}$ at $25 / 20^{\circ} \mathrm{C}$, 10 to $13 \mathrm{~d}$ at $20 / 15^{\circ} \mathrm{C}$, and 13 to $17 \mathrm{~d}$ at $15 /$ $13{ }^{\circ} \mathrm{C}$.

Expt. 3: The efficacy of multiple applications of 1-methylcyclopropene. As shown in Expts. 1 and 2, the efficacy of 1-MCP against ethylene-induced flower wilting in $P$. amabilis 


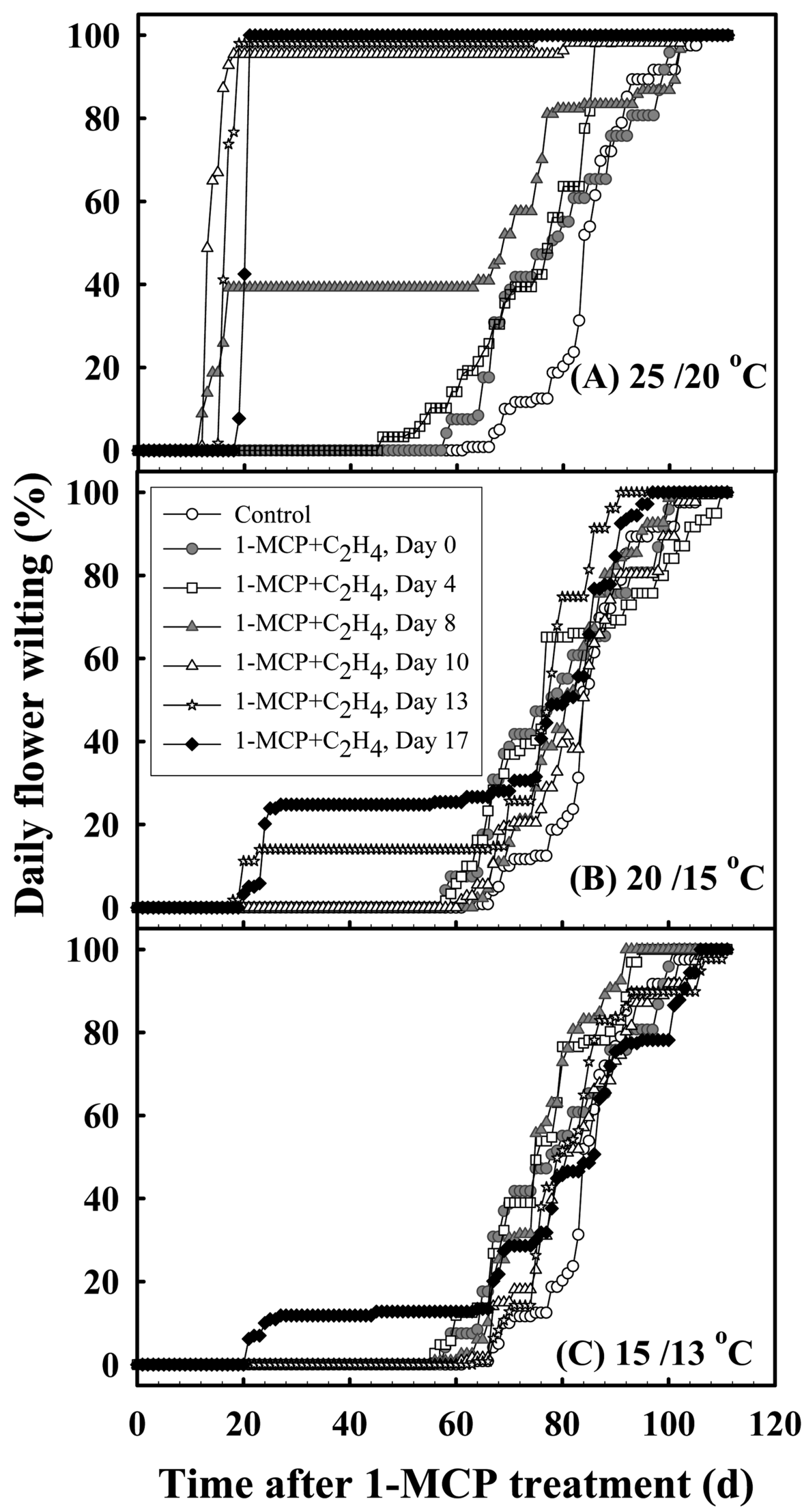

Fig. 3. Influences of temperature on the residual effects of 1-methylcyclopropene (1-MCP) against ethyleneinduced flower wilting in Phalaenopsis amabilis. Plants were fumigated with $0.8 \mu \mathrm{L} \cdot \mathrm{L}^{-1} 1-\mathrm{MCP}$ on Day 0 for $8 \mathrm{~h}$ and placed in phytotrons at day/night temperatures of $25 / 20(\mathbf{A}), 20 / 15(\mathbf{B})$, or $15 / 13{ }^{\circ} \mathrm{C}(\mathbf{C})$. Ethylene treatment $\left(2 \mu \mathrm{L} \cdot \mathrm{L}^{-1}\right.$ for $\left.12 \mathrm{~h}\right)$ was applied on Day $0,4,8,10,13$, or 17 for $12 \mathrm{~h}$. The control group consisted of plants that did not receive either ethylene (treated with only fresh air) or temperature treatment; $n=6$. was transient and was only sustained for 4 to $8 \mathrm{~d}$ at $25 / 20^{\circ} \mathrm{C}$ and 10 to $17 \mathrm{~d}$ at the lower temperature of $15 / 13^{\circ} \mathrm{C}$. Therefore, we used multiple 1-MCP applications (up to three times) to determine if the efficacy of 1-MCP protection could be prolonged.

Without 1-MCP protection, flower-wilting percentage curve rose sharply up to $30 \%$ soon after ethylene treatment (Fig. 4). After a single application of 1-MCP followed by ethylene treatments on Days 6 and 12, the flowerwilting percentage curves remained similar to those of control plants (Fig. 4), while the time taken to achieve specific flower wilting percentages were also similar to control (Table 3 ). This showed that the effect of a one-time 1-MCP application was sustained for more than $12 \mathrm{~d}$.

In plants pretreated twice with 1-MCP, flower-wilting percentage curve of plants treated with ethylene on Day 12 (6 d after the last 1-MCP application) was similar to that of control; we observed a small increase in the flower-wilting percentage, however, after ethylene treatment on Day 18 (12 d after the last 1MCP application; Fig. 4). This result indicated that the efficacy of 1-MCP applied twice, on Days 6 and 12, began to diminish on Day 18 .

In plants treated three times with 1-MCP, no differences in flower-wilting percentages were found between control plants and plants treated with ethylene on Days 18 and 24 (6 and $12 \mathrm{~d}$ after the last 1-MCP application), but the flower-wilting percentage increased rapidly when ethylene was applied on Day 30 (Fig. 4). This result showed that three applications indeed extended the efficacy of 1-MCP from 18 to more than $24 \mathrm{~d}$ compared with only two applications of 1-MCP.

Results of this experiment showed that multiple applications of 1-MCP after some interval were effective in prolonging the protection by 1-MCP against ethylene-induced flower wilting. This study showed that three applications of 1-MCP could protect flowers of $P$. amabilis for 24 to $30 \mathrm{~d}$ (Table 3 ). The experiment was repeated, and similar results were obtained.

\section{Discussion}

Full protection by 1-MCP against ethyleneinduced wilting in flowers of $P$. amabilis was sustained for 6 to $8 \mathrm{~d}$ during the summer in Taiwan and the protection time declined with time thereafter (Fig. 1). In this study, the responses to ethylene of all plants with the same treatment were very consistent; either all of the flowers remained unaffected because of the protection by 1-MCP or wilting occurred as a result of the loss of protection. The exceptions were plants that received ethylene $10 \mathrm{~d}$ after pretreatment with 1-MCP, and these plants exhibited great variations in their responses to ethylene. On some of these plants, all of the flowers and buds wilted; some plants were completely unaffected; whereas flowers in the middle of the inflorescence of other plants wilted (Fig. 2). This phenomenon was also observed in the repeat experiment. These various responses to ethylene indicated that at Day 10, the end of 1-MCP protection was 


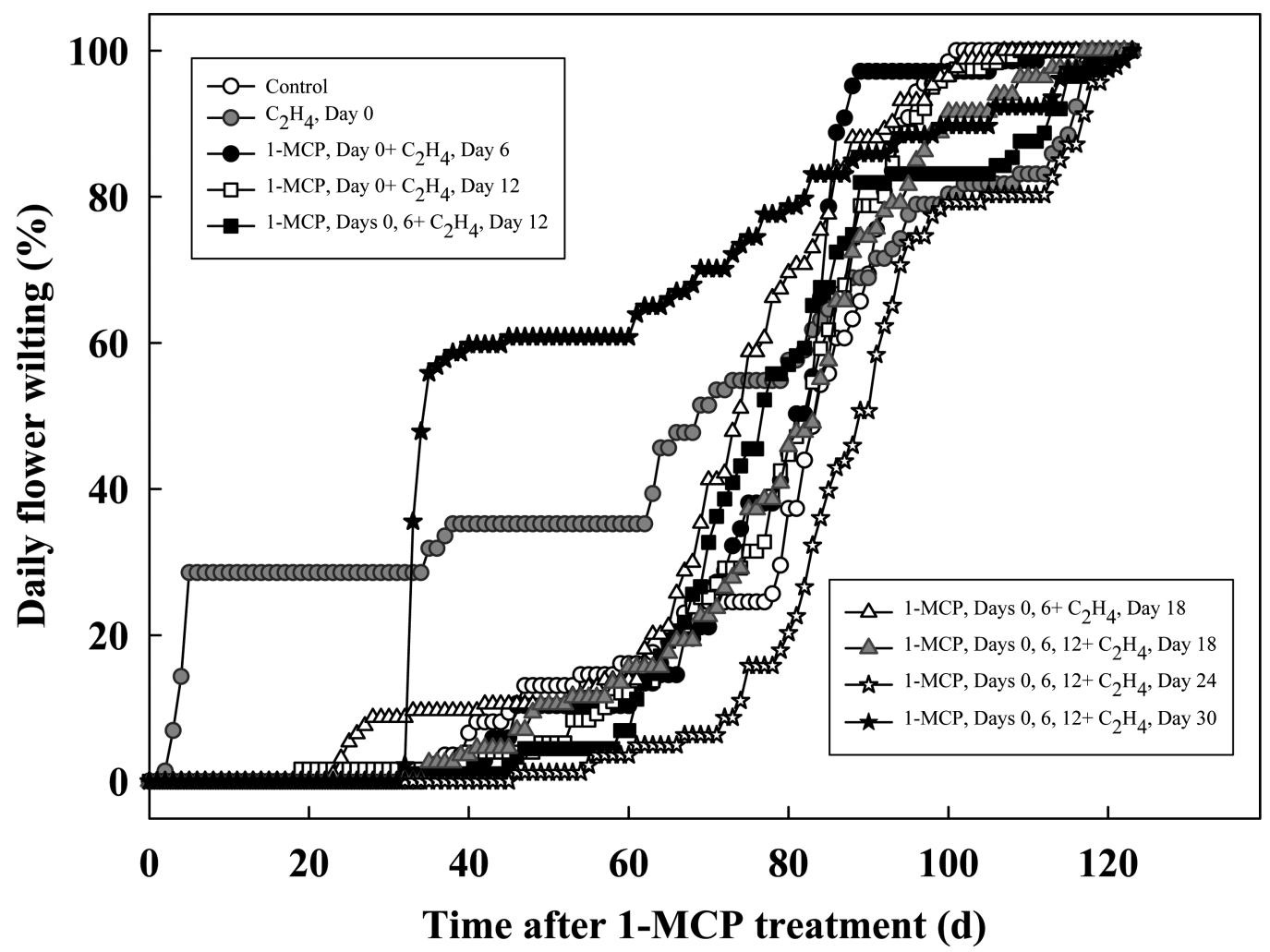

Fig. 4. Residual effects of multiple applications of 1-methylcyclopropene (1-MCP) against ethylene-induced flower wilting in Phalaenopsis amabilis. Plants were fumigated with $0.8 \mu \mathrm{L} \cdot \mathrm{L}^{-1} 1$-MCP once (Day 0), twice (Days 0 and 6), or three times (Days 0,6 , and 12) followed by $2 \mu \mathrm{L} \cdot \mathrm{L}^{-1}$ ethylene treatment on Day 6 or 12 for one 1-MCP application, Day 12 or 18 for two 1-MCP applications, and Day 18, 24, or 30 for three 1-MCP applications. Control plants were treated with air but did not receive either 1-MCP or ethylene application; $\mathrm{n}=6$.

Table 3. Effects of multiple applications of 1-methylcyclopropene (1-MCP) on its residual protection against ethylene-induced flower wilting in Phalaenopsis amabilis.

\begin{tabular}{llccrr}
\hline & $\begin{array}{c}\text { Ethylene } \\
\text { treatment }\end{array}$ & \multicolumn{4}{c}{ Time to achieve a specific flower wilting percentage $(\mathrm{d})^{\mathrm{x}}$} \\
\cline { 2 - 6 } 1-MCP treatment & Greater than 0\% & $50 \%$ & $70 \%$ & $100 \%$ \\
\hline Now $^{\mathrm{w}}$ & No (control) & $60.0 \mathrm{ab}^{\mathrm{v}}$ & $80.3 \mathrm{a}$ & $85.8 \mathrm{ab}$ & $93.3 \mathrm{ab}$ \\
No & Day 0 & $14.7 \mathrm{c}$ & $52.5 \mathrm{~b}$ & $75.0 \mathrm{bc}$ & $99.2 \mathrm{ab}$ \\
Day 0 & Day 6 & $59.6 \mathrm{ab}$ & $80.2 \mathrm{a}$ & $83.2 \mathrm{ab}$ & $91.8 \mathrm{ab}$ \\
Day 0 & Day 12 & $50.8 \mathrm{ab}$ & $80.7 \mathrm{a}$ & $89.3 \mathrm{ab}$ & $96.3 \mathrm{ab}$ \\
Days 0,6 & Day 12 & $54.5 \mathrm{ab}$ & $81.0 \mathrm{a}$ & $87.8 \mathrm{ab}$ & $98.0 \mathrm{ab}$ \\
Days 0, 6 & Day 18 & $41.3 \mathrm{~b}$ & $76.7 \mathrm{a}$ & $80.8 \mathrm{~b}$ & $91.2 \mathrm{ab}$ \\
Days 0, 6, 12 & Day 18 & $52.0 \mathrm{ab}$ & $84.0 \mathrm{a}$ & $90.5 \mathrm{ab}$ & $100.7 \mathrm{a}$ \\
Days 0, 6, 12 & Day 24 & $63.5 \mathrm{a}$ & $92.0 \mathrm{a}$ & $105.5 \mathrm{a}$ & $108.8 \mathrm{a}$ \\
Days 0,6,12 & Day 30 & $40.7 \mathrm{~b}$ & $53.0 \mathrm{~b}$ & $55.7 \mathrm{c}$ & $82.3 \mathrm{~b}$ \\
\hline
\end{tabular}

${ }^{2}$ Plants were treated for $8 \mathrm{~h}$ with $0.8 \mu \mathrm{L} \cdot \mathrm{L}^{-1} 1-\mathrm{MCP}$ on the designated days or left untreated.

${ }^{y}$ Plants were fumigated with $2 \mu \mathrm{L} \cdot \mathrm{L}^{-1}$ ethylene for $12 \mathrm{~h}$ on designated days.

${ }^{\mathrm{x}}$ Calculated from Day 0 .

${ }^{\mathrm{w}}$ Control plants were treated with air but did not receive either 1-MCP or ethylene application.

v Means followed by different letters in a column are significantly different at $P \leq 0.05$ by the least significant difference test; $\mathrm{n}=8$.

almost reached. Sisler and Serek (1999) suggested that the reason for such reduced protection may be that 1-MCP molecules detach from the ethylene receptors or new receptors are regenerated (Sisler and Serek, 1999). Recent research on carnations (Dianthus caryophyllus 'White Sim'), however, showed that a supersaturated concentration $\left(1000 \mu \mathrm{L} \cdot \mathrm{L}^{-1}\right)$ of ethylene was unable to overcome the protection afforded by 1-MCP treatment, which suggests that 1-MCP binding is irreversible (Reid and Çelikel, 2009). In this study, the duration of protection of $P$. amabilis flowers afforded by $1-\mathrm{MCP}$ seemed to vary with the age of the flowers. Among all of the flowers and buds in inflorescences, nearly opened buds were more susceptible to wilting if treated with ethylene $10 \mathrm{~d}$ after 1-MCP pretreatment (Fig. 2). This observation may be explained in terms of the availability of functional ethylene receptors and the innate sensitivity to ethylene in buds and flowers. Nearly open buds may be in a developmental stage when ethylene receptors become functional or when new receptors are being actively regenerated. Hence, nearly open buds became more sensitive to ethylene in the time between the 1-MCP pretreatment and subsequent ethylene treatment. Opened flowers of $P$. amabilis were more sensitive to ethylene than flower buds; moreover, the sensitivity increased with age, both among flowers and among flower buds (Lin, 2006; Lin et al., 2003). In this study, however, we observed that protection against ethylene in opened flowers by 1-MCP was sustained for a longer time than in nearly opened buds, suggesting the possibility of a lower rate of receptor regeneration in open flowers. Younger buds were less susceptible to wilting after ethylene treatment on Day 10, because younger buds have an innately lower sensitivity to ethylene (Lin, 2006; Lin et al., 2003). This lower sensitivity to ethylene may be the result of fewer functional ethylene receptors in younger buds.

Low temperature (i.e., from 25 to 20.7 and $12{ }^{\circ} \mathrm{C}$ ) prolonged 1-MCP protection against ethylene in Pelargonium peltatum (Cameron and Reid, 2001). Low temperatures, however, are also efficient in delaying the response to ethylene after the binding of ethylene receptors and ethylene (Serek et al., 2006). In this study, responses of plants to ethylene treatment were observed for several days. Therefore, to avoid effects of temperatures on the ethylene response after the binding of ethylene to its receptors, we placed the Phalaenopsis plants in the same place at the same temperature after ethylene treatment. Full protection of $P$. amabilis flowers by 1-MCP against ethylene was sustained for 4 to $8 \mathrm{~d}$ at day/ night temperatures of $25 / 20^{\circ} \mathrm{C}, 10$ to $13 \mathrm{~d}$ at $20 / 15^{\circ} \mathrm{C}$, and 13 to $17 \mathrm{~d}$ at $15 / 13{ }^{\circ} \mathrm{C}$ (Fig. 3). From 15 to $25^{\circ} \mathrm{C}$, the temperature coefficient $\left(\mathrm{Q}_{10}\right)$ of flower respiration in Phalaenopsis 
Snow Mist 'Large Sepal' was 1.8 (Lee and Lin, 1992). Therefore, higher metabolism may accelerate the loss of efficacy of 1-MCP. In this study, the effect of temperature on 1-MCP efficacy was also shown when experiments were done in different seasons. After one-time treatment with 1-MCP, P. amabilis resisted ethylene-induced flower wilting for 6 to $8 \mathrm{~d}$ in the summer (Fig. 1) and for at least $12 \mathrm{~d}$ in the winter (Fig. 4). We deduced, therefore, that higher temperatures resulted in shorter 1-MCP protection times.

The transient efficacy of 1-MCP is necessary for fruit-ripening control during postharvest treatment (Hoeberichts et al., 2002). The goals of postharvest treatments of ornamental plants, however, are to maintain product quality and extend the shelf life for as long as possible. The efficacy of 1-MCP in delaying fruit softening of 'Redchief Delicious' apples (Malus sylvestris var. domestica) increased with a greater application frequency (once every week, every 2 weeks, 1 month, or 1 year) when the fruit was stored at 5 to $20{ }^{\circ} \mathrm{C}$ (Mir et al., 2001). In this study, multiple applications of 1-MCP were an efficient method to extend protection times against ethylene stress in flowering $P$. amabilis (Fig. 4). Two applications of 1-MCP protected flowers against ethylene for only 12 to $18 \mathrm{~d}$, but three applications prolonged the protection time to 24 to $30 \mathrm{~d}$ (Fig. 4).

In conclusion, the efficacy of 1-MCP against ethylene-induced flower wilting in $P$. amabilis is transient, and its protection duration is predominantly affected by temperature. Once the efficacy diminishes, 1-MCP retreatment can extend the protection time; retreatment with 1 -MCP every 6 to $8 \mathrm{~d}$ in the warm season and every 10 to $12 \mathrm{~d}$ in the cool season can reduce ethylene-induced flower wilting in Phalaenopsis.

\section{Literature Cited}

Cameron, A.C. and M.S. Reid. 2001. 1-MCP blocks ethylene-induced petal abscission of Pelargonium peltatum but the effect is transient. Postharvest Biol. Technol. 22:169-177.

Hew, C.S. and J.W.H. Yong. 2004. The physiology of tropical orchids in relation to the industry. 2nd Ed. World Scientific Publishing Co. Pte. Ltd., Singapore.

Hoeberichts, F.A., L.H.W. van der Plas, and E.J. Woltering. 2002. Ethylene perception is required for the expression of tomato ripeningrelated genes and associated physiological changes even at advanced stages of ripening. Postharvest Biol. Technol. 26:125-133.

Lee, N. and Y.S. Lin. 1992. Respiration of Phalaenopsis flowers. J. Chinese Soc. Hort. Sci. 38: 228-240 [in Chinese with English abstract].

Lin, H.H., N. Lee, and T.H. Chang. 2003. Effects of ethylene and 1-MCP pretreatment on flower wilting of potted Phalaenopsis amabilis var. formosa Shimadzu. J. Chinese Soc. Hort. Sci. 49:199-210 [in Chinese with English abstract].

Lin, W.L. 2006. Effects of ethylene and 1methylcyclopropene on flower longevity in Phalaenopsis amabilis. MS thesis, Natl. Taiwan Univ. Taipei, Taiwan [in Chinese with English abstract].

Martínez-Romero, D., G. Bailén, M. Serrano, F. Guillén, J.M. Valverde, P.Z.S. Castillo, and D. Valero. 2007. Tools to maintain postharvest fruit and vegetable quality through the inhibition of ethylene action: A review. Crit. Rev. Food Sci. Nutr. 47:543-560.

Mir, N., M. Canoles, and R. Beaudry. 2004. Inhibiting tomato ripening with 1-methylcyclopropene. J. Amer. Soc. Hort. Sci. 129:112-120.

Mir, N.A., E. Curell, N. Khan, M. Whitaker, and R.M. Beaudry. 2001. Harvest maturity, storage temperature, and 1-MCP application frequency alter firmness retention and chlorophyll fluorescence of 'Redchief Delicious' apples. J. Amer. Soc. Hort. Sci. 126:618-624.

Philosoph-Hadas, S., O. Golan, I. Rosenberger, S. Salim, B. Kochanek, and S. Meir. 2005. Efficiency of 1-MCP in neutralizing ethylene effects in cut flowers and potted plants following simultaneous or sequential application. Acta Hort. 669:321-328.

Reid, M. and F.G. Celikel. 2009. Use of 1methylcyclopropene in ornamentals: Carnations as a model system for understanding mode of action. HortScience 43:95-98.

Segliea, L., E.C. Sisler, H. Mibusa, and M. Serek. 2010. Use of a non-volatile 1-MCP formulation, N,N-dipropyl (1-cyclopropenylmethyl) amine, for improvement of postharvest quality of ornamental crops. Postharvest Biol. Technol. 56:117-122.

Serek, M., E.J. Woltering, E.C. Sisler, S. Frello, and S. Sriskandarajah. 2006. Controlling ethylene responses in flowers at the receptor level. Biotechnol. Adv. 24:368-381.

Sisler, E.C. and M. Serek. 1999. Compounds controlling the ethylene receptor. Bot. Bull. Acad. Sin. 40:1-7.

Sun, Y., B. Christensen, F. Liu, H. Wang, and R. Müller. 2009. Effect of ethylene and 1-MCP (1-methylcyclopropene) on bud and flower drop in mini Phalaenopsis cultivars. Plant Growth Regulat. 59:83-91. 